\title{
AMERICAN PHILOSOPHY OF RELIGION FROM A EUROPEAN PERSPECTIVE: THE PROBLEM OF MEANING AND BEING IN THE THEOLOGIES OF IMAGINATION AND PROCESS
}

\author{
FRITZ BURI*
}

The presumptuous task of presenting to this honorable convention a European perspective on American philosophy of religion contains two difficulties. One consists in the fulness of material, too much to be treated in an hour. The second consists in the question: how does "European" differ in meaning from "American"? The first difficulty forces me to make a selection from the varieties of American philosophies of religion, to which-also in my mind-theology belongs as a principal part. From the fulness of American philosophy of religion as represented by outstanding theological and philosophical thinkers of this country, I shall choose two types: the so-called theology of imagination and process theology. In dealing with these two manifestations we obtain at the same time a certain characterization of European theology and philosophy. In contrast to the American situation we have in Europe no real equivalent to either the theology of imagination or process theology and until now neither has found a great echo there, although both of them have important roots in Europe, too. So you may take it as a sign of repentance for my brethren when I direct my European perspective on American philosophy of religion to the theologies of imagination and process.

There is, however, a further reason for this choice. From its origin in New Testament eschatology and in view of the non-arrival of the Parousia, Christianity has been occupied in different formulations

*Professor of Systematic Theology (Emeritus) at Basel University, Dr. Buri has lectured and taught in the United States and Japan and is widely acknowledged as the leading European interpreter of North American theology and philosophy of religion. Professor Dr. Buri's essay was presented as a 75th Anniversary Lecture at the 1984 annual meeting of the American Academy of Religion. For the Academy, the Editor expresses gratitude to Professor Harold H. Oliver (Boston University School of Theology) for the present English translation of Professor Buri's German text. 
with the problem of meaning and being throughout its whole history, searching for ever new solutions to it. In contrast to other kinds of theology and philosophy of religion the theology of imagination and process philosophy and theology are basically struggling with this problem, even when they are not always sure of its historical roots, or when they transform its mythological form into a more or less secular philosophical-speculative one. Their truth lies not so much in their pretended solutions to the meaning-being problem as in their striving with it, as is the case in the biblical understanding of history-and throughout the whole history of Christianity.

That is the point I should like to make in my following confrontation with the theologies of imagination and process which is presented as a contribution not only to the American but to the European philosophical-theological situation as well, and possibly also as a basis for a real encounter with Far Eastern thinking. For this purpose I have chosen two pairs of representatives of theologies of imagination and process, and a third pair who combine them. For the first I have chosen Ray L. Hart and Gordon Kaufman; for the second, John Cobb and Schubert Ogden; and, for the last, David Tracy and Robert Neville. I think that the outstanding position of these thinkers justifies my restricted choice, and I hope that those who represent other kinds of thought will profit from the critique, also, and that those whom I critique will have some understanding for my bold undertaking to try to understand them better than they understand themselves.

I

We shall begin our series with Ray Hart who, with his book, Unfinished Man and the Imagination (1968), was to my knowledge the first to introduce the concept of imagination to the American theological scene, although not initially with great success because of the difficulty of reading his book. In one remark he mentions Horace Bushnell's book, Our Gospel a Gift to the Imagination (303). Otherwise he comes to terms mainly with philosophers, with Aristotle and with Kant's concept of the transcendental imagination, appeals to historians of literature and philosophers of language, such as Dilthey and Gadamer, and also makes use of Husserl's phenomenology. In an appendix he deals with "pre-modern" cognates of his concept of imagination in catholic and protestant scholasticism.

This concept gained special significance for Hart when he endeavored to use the kind of knowledge inherent in it to render intelligible the concept of language- or word-event taken over by him from the Bultmannian school. While Bultmann still spoke of the Word of God as an "eschatological event" whose mythological form is to be 
interpreted existentially, that is, as an expression of a selfunderstanding which finds its fulfillment of meaning in an alignment with it, several disciples of Bultmann abandoned the questionable concept "eschatalogical" because it appeared to them still too mythological for speaking of the proclaimed Christ event as a languageevent which-mediated by language-is said to occur in faith. Without entering into a discussion of the ontological significance which arose with this existential-ontological concept, that is, to what extent it occurs in the divine and to what extent in the human realm, Hart believes he can resolve the difficulty of the beingness of meaning which arose in connection with the understanding of the Christ event as language-event, and can make it more intelligible, by more accurately describing "the mystery of the Word of God" for believers in terms of imagination.

That he is concerned primarily with the question of meaning is evident at the beginning of his book where he deplores the fact that for modern man the Christian faith is no longer what it had been for so long, namely, a "house of meaning". But he is convinced that it can become so again if only the "Given" of theology-the event of the Word of God-can again be made valid. For this purpose it is necessary to distinguish between two kinds of language: a "first order language" which-as he characterizes it-"preserves that body-heat intimacy which obtains between apprehension and the reconfiguration of linguistic debris which expresses it" and "as such is eventful", and a "second order language" which "withdraws from the languageevent in order to place it in a larger frame, to connect it with apprehensions embedded in the language of common currency, and so to enhance its communicability in and to the public domain" (28). In contrast with what is "immediately given" for theology, namely, the "Word of God" as the "event of the Word of God in human audition" and to the "paradigmatic events" which have "left the stamp of their immediacy upon language" (44), theology belongs to second order language; and the decisive question for theology may be "whether its own linguistic debris can be used to erect a new house of first order language; i.e. can be used to bring the subject-matter of theology to language-event" (28). Otherwise than in a mere philosophy of culture or even in a neo-orthodox "senkrecht von oben" (118) this can only happen in the imagination as an "event-inverbalizing language" (49).

It is understandable that Hart in this connection also mentions Kant's use of the concept of imagination in his Critique of Pure Reason (186, 236, 338f.). For just as Kant in his transcendental imagination deals with the ontological character of perception, representation and comprehension which are bound together in it into a 
unity, so also Hart vindicates the ontological character of his imagination not only-in contrast to Kant-in the sphere of phenomenality, but for salvation facts of faith knowable as such. Hart reproaches Kant not only for the lack of such an ontological knowledge, but also for omitting the role of feeling and for failing to take into account the historicity of the understanding. With his combination of imagination and will- "Imagination is the intellectual organ of the will" (196)-he already stands nearer to Fichte when in his own "anthropological analysis" he replaces the Fichtean self-positing by an indefinable "being situated and self-situating" (156n71) and sees in it the basis for an "ontology of revelation" (109ff.).

There are experiences of meaning - the hindrances which resist the will to meaning and the creative realization of meaning which arises out it in the imagination-on the basis of which Hart believes he can accede to pronouncements about being. When the consciousness of reality is shaken because of its meaning and points beyond itself, man can become ready to accept the gospel of God's salvation in Christ as valid for himself and is thus able to understand his existence in the world coram Deo.

Hart describes in detail this eventful becoming of salvation in selfand world-understanding by recourse to a "hermeneutical spiral" (6If.) and to Gadamer's "horizon-fusion" (58) by means of Husserlian phenomenology and by analogy to the nature of the work of art. Instead of a demonstration of the problematic of this existentialontological meaning-being-construction-which would not be very fruitful-I should like to call attention to a passage in Hart's explication in which he speaks of a possibility-though not for himself-of overcoming this problematic. This takes place in connection with a discussion of the concept of potentia obedientalis, that is, the predisposition of man for divine grace (177f.).

Hart correctly rejects the use of this concept for a intra-divine occurrence, as in Ebeling, in favor of an event in human selfunderstanding, in which the awareness of incompleteness forms the point of contact of true human existence. He speaks here in the words of Merleau-Ponty of an "antinomy of grace" as the "turning" point "where the real self ". as the trembling of a unity exposed to contingency and tirelessly recreating itself' accedes to being constituted out of community with being - care-fully refunded for its good out of its ownmost potency" (178). This corresponds to the formulation of Martin Buber which he also mentions: "It depends on me" and "I am given over for disposal" (177). One could here also recall Jasper's "reception of one's self as a gift" (Sich-selber-geschenktBekommen).

Hart, however, mentions Jaspers only in a remark referring to a 
secondary source, for he regards this philosophical self-understanding as insufficient, because "the Christ-event", "the subject-matter of theology" which-in Hart's view-"is what [theology] and it alone can say" does not get stated. Since for all his stress on the necessity for imagination Hart is and remains a theologian of the word, he misses the chance to see in the forms of a not-specifically Christian, more universally human self-understanding which experiences itself in its enactment as graced, the substance of the Christ-event and thus as a symbol for the meaning-possibility of human existence attested and experienced in these forms, and thus remains stuck with his imagination in the "word-prison" of an ambiguous "language-event".

What about the other representative of the theology of imagination, Gordon Kaufman? Did he take the opportunity to be liberated from the "word-prison" in which Hart, no less than Bultmann, though in different ways, is confined? Does Kaufmann take the chance indicated of understanding Christian existence as symbolic of human self-understanding, or with his concept of imagination does he become entangled ever deeper in its snares?

Initially it could seem that the former is the case. In his first book of essays, God the Problem (1972), there is a chapter that carries the title, "God as Symbol", to which he assigns an important role in the development of his thinking. While in his Systematic Theology (1968) he reckoned with the objectivity of salvation-facts in a manner more massive than does Hart, here he begins to understand these as products of the symbolizing knowledge of faith, which is quite different from Hart's persistent ontological talk about a "languageevent".

For this turn in the development of his theology Kaufman has provided a comprehensive justification in his Essay on Theological Method (1979). In the collected essays on essential topics of Christian theology in his second book of essays, entitled, The Theological Imagination (1981), he makes use of this method, as the subtitle shows: "Constructing the Concept of God". While with Hart imagination, since it occurs as an "intellectual organ of the will", represents the sphere in which the revelation of God occurs as "language-event", with Kaufman it is man who in imagination constructs the concepts of the religious tradition, so that they form for him "constructs of imagination". Language-events are apparently quite different from imaginative constructs, in that the former occur in imagination, while the latter occur through imagination. In comparison with Hart's Husserlian foundational theory, Kaufman's epistemological conceptualizing is less demanding, as is evident in the fact that he speaks in an undifferentiated way of "image/concepts" (1981: 14).

When considering imagination Kaufman also differs from Hart in 
taking account not only of Christian theology and especially its Christ-event; for he sees imagination as a longing for meaning and orientation to meaning in all human culture and in the veneration of meaning-giving powers in all religions (1981: 172ff.). This human estimation makes possible for him a positive evaluation of the world of religions, as is not the case in Hart's restriction of the imagination to the Word of God given only for theology.

This enlarged way of regarding the history of culture and religion becomes effective in Kaufman's understanding of revelation in two ways: on the one hand, in a negative-critical manner, insofar as it liberates him from the exclusivity claim of Christian mythology, and on the other hand, in a positive manner insofar as this cultural and historical view in whose context he discusses the biblical-Christian history of salvation offers him an alternative for what is put into question with this kind of consideration, in that for him the historically conditioned biblical-Christian view is now replaced by the religious and cultural evolution of mankind. As he appeals for this to a salvation-historical conception of creation, Kaufman does not hesitate to include nature in this universal conception of world and history (1981: 209f.), and to attribute to man, whose completion he sees in the image of Jesus Christ (1981: 114ff.), a special significance as the center of the possible realization of salvation and meaning in the whole of being.

Kaufman sees a difference between the two universal worldviews only insofar as the mythological one is cultically more effective than the more abstract-scientific and metaphysical one, but which for the sake of its effectiveness has to be corrected by the latter. For all their differences what is common to both formulations, according to Kaufman, is that they are constructions of the human longing for completion of meaning and that according to their mutual testimony this completion of meaning consists in the humanization of man in active love.

In the measure of their humanizing effect as in the truthfulness of the religious or metaphysical grounding of this historical effectiveness Kaufman believes to have found the criterion by which the truth of the two constructions can be judged in their similarities and differences. Under this perspective he submits these different patterns of an unending critical examination and demands correspondingly also their continuing reconstruction.

Since Kaufman is a theologian of the Church it. is quite obvious that in this concern he is especially occupied with the God whom Christians in "worship and service" trust as the meaning-ground of human existence, while for him the corresponding abstract-metaphysical worldviews form only its negative background insofar as he, with 
Kant, considers an empirical-rationalistic or speculative proof of God as impossible. With Kaufman it is imagination which takes over the role which Kant in this connection assigns to the practical reason for which God is a postulate of morality. For the humanizing significance of the idea of God Kaufman appeals not only to the history of culture and religion in general, but in particular to his development in the history of the biblical faith in God which peaks in the figure of Jesus as the "model of true humanity". In the humanizing force of faith in God which actualizes human nature he believes he can detect the proof that it deals "with actuality, not merely fantasy", and that God as meaning-ground of reality is simultaneously its ground of being. "Faith", declares Kaufman, "lives from a belief in, a confidence that, there is indeed a cosmic and vital movement . . . toward humaneness, that our being conscious and purposive and thirsting for love and freedom is no mere accident, but is undergirded somehow in the very nature of things". For such a faith "God is the personifying symbol of that cosmic activity which has created our humanity and continues to press for its full realization" (1981: 49f.).

For this kind of thought in which Kaufman comes to this connection between the ground of being and meaning in God, it is significant that he interrupts the critical discussion of the mythically transparent picture of God just at the point where it comes into conflict with the modern image of man and history (1981: 38f.) and that he takes it up anew after having exhibited the meaning-giving moments in reality contained therein, in order to conclude from them the existence of God, and thus to establish the reality of God in its function as the fulfilment of the human longing for meaning.

The imagination in which this occurs consists therefore not only in the fact that this theologian-like the famous man from Muenchhausen-thinks he can draw out of his own head-that is, from his longing for meaning - the problematic of human meaning, but that the place at which he could connect with it-in contrast to Muenchhausen-he takes as a product of his imagination. Or, to illustrate his situation with a less malicious, but by him seldom used image: On a map he designates individual points of meaning by means of which he thinks he is able to reach the goal of complete realization of meaning (1972: 100; 1979: 28). But not only does this destination lie outside the map, but with the intelligibility of these milestones he runs the risk that the map which he inscribes renders only an imaginative landscape of longing and does not provide access "to the things as they really are". If, despite this, he appeals to Feuerbach's judgment that the transcendence of his concept of God excludes the illusion of a mere satisfaction of needs (1981: 43), it cannot achieve this purpose 
for him, because it too represents such a construct of the imagination arising out of the human need for meaning.

II

Obviously it is not sufficient-with Kaufman-to enlarge the half-mythological Christ-event, to which Hart refers the imagination, into a history of culture which peaks in Christianity. This the process theologians seem to have known when they have attempted to understand being as such as an occurrence of meaning and to include Christology in it. Two of the most representative contemporary process theologians have made this attempt, each in his own way: John Cobb, in his most extensive publication, Christ in a Pluralistic Age (1975) and in his systematic sketch, Process Theology, published a year later with his pupil, David Griffin (1976); and Schubert Ogden, in his The Point of Christology (1982) which appeared sixteen years after his collection of essays, The Reality of God (1966). For Cobb, as for Ogden, Christ represents the center of meaning of WhiteheadianHartshornean process philosophy, with whose help they believe they can solve the problems of traditional Christian salvation history, and with their philosophical mentors they base their de-substantialized metaphysics of meaning on experience. Both also confess that they have passed through significant changes in their theological development, in that for their originally rationalistic thinking the imaginal or symbolic has gained decisive significance. But in contrast to the theologians of imagination with whom they share the need for meaning in experience, they do not orient it merely to history, or to a single event; rather as they see it, the cosmic process as a whole constitutes the event of meaning in which the man of faith participates, for it culminates in Christ and is pervaded by him.

John Cobb begins his Christology by taking on André Malraux's art-historical thesis that in Western art the supra-earthly figure of the redeemer is increasingly replaced by an earthly figure who finally totally disappears in the plurality of profane styles. While Malraux sees in this course of the history of art which he analyzes a proof for the irresistible weakening of Christianity, Cobb believes he can draw just the opposite conclusion from Malraux's view, insofar as he believes he can see in the transformation of the divine figure of the Christ into a human one and the subsequent richness of new creative styles a typical example of that with which Christian faith deals, viz. the incarnation of God in Christ and the "creative transformation" which originated in this divine occurrence of salvation and became effective not only in the history of humanity, but even in the entire cosmos. This takes place in forms which are not limited to Christian- 
ity, but appear in other religions as well. Cobb summarizes his positive interpretation of Malraux's thesis as follows: "The process that relativized the Christ figure and then omitted it altogether was itself the power represented by the Christ figure, namely, the Christ himself" (1975: 54).

As this sentence indicates, Cobb distinguishes between the "Christ figure" and "Christ himself" as the "power" represented in the figure. From the art-historical discussion it is obvious that Cobb also employs for the Christ-figure the concept of "image" as is also customary in theology. But it is out of theology that there arises the concept of "Logos" which he employs for "Christ himself" and his "creative power". While the image is a way of depicting what is meant imaginally or even in abstract conceptuality, with "Christ himself" or the "Logos" we are dealing not with its depiction, but with its "power"; i.e., as Cobb says, with an "ontological status" and-as we can now say on the basis of the theologians of imagination previously treated-not merely with an affair of the imagination. To be sure, the latter emphasize that they deal not merely with products of the imagination; rather, to such products are to be ascribed veridical value provable in reality. It is in this sense that Cobb makes use of the imagination (1975: 75), insofar as the significance of the "world of images" has been disclosed to him, as he notes in the Foreword (1975: 14). But he regards an ontological foundation as indispensable for his Logos metaphysics and is convinced that with the help of Process Philosophy it is also possible.

In this sense he appeals to Whitehead, as he has done in all of his publications, so now in all three parts of this book in which he represents "Christ as the Logos", "Christ as Jesus" and "Christ as Hope". While in this book this takes place only in the form of individual characteristics and their application in aspects of Christology previously discussed, in the book, Process Theology (1976), which he published with David Griffin, the epistemological and metaphysical foundation of his Christology and of his entire theology is set forth in a systematic way. David Griffin, to whom was entrusted the first four chapters, argues in a very apodictic way, in that he simply presupposes the validity of Whiteheadian Process Philosophy. Rather than hindering us, this fact gives us reason to register critical objections against some of the individual expositions of this thinking and its application in theology.

Right at the beginning Griffin gives us reason for such a critique when, with reference to Whitehead's identification of "actual occasions" and "occasions of experience", he declares that Process Philosophy understands human experience "as a high-level exemplification of reality in general". For this "high-level" he refers to the 
reflexive experience characteristic of man-an experience which however is grounded in a "pre-reflexive" universal processual event independent of the former, but with which it is "merging" and therein experiences its "metaphysical depth" (Cobb \& Griffin, 13).

This mutual dependence of human experience and cosmic event does not prevent him from speaking of this state of affairs by conceptually distinguishing between two kinds of process: a temporal process consisting of a transition from one real occasion to another in such a manner that the individual entities "perish immediately upon coming into being"; and a process which occurs within these individual occasions as they become concrete or "grown together" as they originate, but which now-in contrast to the former-are "timeless" (Cobb \& Griffin, 13f.).

Aside from the fact that this doctrine of process is an "hypothesis" which cannot be proved scientifically but represents a speculative extension of a process interpretation of human experience into something universal and cosmic, this speculation is burdened with difficulties: What about the timelessness of this moment of process within its temporality? Griffin explains that "concrescence" does not entail "things which endure through a tiny bit of time unchanged", but with things which need just "that bit of time to become" (Cobb \& Griffin, 15) If, on the one hand, they need time in order to become, then they are not timeless indeed. On the other hand, the "experience of the "eternal Now" "is incompatible with the basic principle of thinking "that all reality is fundamentally process". If "to be real" means to be in process, then becoming concrete would not exactly be "reality".

That here a basic problem of Process Philosophy is at stake becomes evident in Cobb's debate with the Buddhist doctrine of "dependent co-origination" (Pratitya-samutpada) which dissolves all occurrences into a flux which cancels every temporal thingness, but loses on that account the personality of man, as Cobb rebukingly speaks of it (1982).

This problematic character of Process Thought becomes even more apparent in the characterization of "concrescence" as "enjoyment" (Cobb \& Griffin, 16ff.). "To be, to actualize oneself, to act upon others, to share in a wider community, is to enjoy being an experiencing subject". For Whitehead this enjoyment occurs universally. "Every unit of process, whether at the level of human or of electronic events, has enjoyment". The distinction consists only in its becoming conscious, and this depends on the selective choice by which each unit of process determines in a creative way what it accepts from the past and transmits as an impetus to new experience, with the result "that each occasion is a selective incarnation of the whole past 
universe" and "that our activities will make a difference throughout the future" (Cobb \& Griffin, 23).

What really takes place here: the single occasion or the universe? Not one without the other, but rather only one with the other in a selection and a particularity which belongs to the nature of the process as an event that is simultaneously temporal and timeless. Or with reference to what is human: human experience serves as a model of the cosmic process which in turn actualizes itself most completely in man's becoming aware of its universal character as a model. Because this speculation deals with a level of self-consciousness in which there is a loss of the subject according to Pratitya-samutpada and in a way which threatens process thinking, it occurs to us that process thought is nothing but a construction by which human beings in the world provide a meaning that is anchored in being as becoming. Griffin confirms this wishful character of process thought when-in view of our experience of the world as "a place of process, of change, of becoming, of growth and decay"-he speaks of "our basic religious drive" as "to be in harmony with the fully real" and of its fulfillment not in a flight from the world, but in an "immersion in the process" (Cobb \& Griffin, 14).

While there are process philosophers who do not consider the religious striving for harmony and understand it purely in an immanent way, process theologians take it into account by including in the universal process the idea of God as its origin and effect. In contradistinction both to classical substance metaphysics and the thought of a "becoming God" they do that in the form of a "dipolar theism" in that they distinguish between God's "primordial and consequent" nature in a way dependent upon Whitehead and Hartshorne's partial correction of the former's terminology (Cobb \& Griffin, 43). The two poles of the "creative-responding love" of God which as the "initial aim" toward creative transformation and also its "eros" actively permeate the processual event in each of its single acts and allows this absolute activity to complete itself in a passivity which respects human behavior-these two poles have as their metaphysical transcendental equivalents the becoming and perishing which characterize the processual event. Both of these poles are incarnate in the Logos, i.e. in its incarnation in Christ.

That is the point where Cobb in both of the books mentioned introduces his Logos Christology and from which he interprets the person of the historical Jesus as well as trinitarian-Christological dogma and from which there unfold eschatology and the doctrine of the Church-and from which finally he speaks of special problems like ecology, relations with other religions, especially Buddhism, feminist theology, etc. 
As a whole, this process theology, which is carried through with great skill, although fraught with questionable vagueness, represents an interesting counterpart to the theology of imagination. Both are concerned with establishing the meaning of human existence. Their difference lies in the fact that the latter seeks with the help of the imagination to find it in the Christ event, or in its expansion into the history of culture or religious imagination; whereas process theology thinks it can anchor both moments in a speculative-cosmic metaphysical understanding of being as becoming. The problematic character of both of these undertakings consists precisely in their attempt to establish meaning in terms of an optimism about the meaningfulness of being which is not fully sensitive to the problematic of meaning.

In a way matched by few other process theologians, Schubert Ogden has been engaged in an extension and validation of the metaphysics of the dipolar God which is characteristic of this kind of theology. But in this circle he is the one who-as he confesses in his book on Christology-has become "increasingly sceptical" about this undertaking (1982: 135). However promising this may sound, the consequences which he has drawn out of this change of attitude about metaphysics which sounds much like a conversion are even less convincing. For the "boundless love of God", for which he has been concerned from the beginning, he no longer wishes to refer to its embodiment in the historical Jesus and its metaphysical exemplification in dipolar process metaphysics, but primarily to the apostolic witness of the experience of God's love associated in the tradition with this figure and which-as he claims-gives us the victory (1982: 126ff.).

In connection with our question about the possibility of founding the meaning of human existence we have to deal neither with the methodology which Ogden uses in the interpretation of the eschatological witness of faith nor with its results; rather we note that in both respects he overcomes neither the problem of faith and history unsolved in the theology of Ritschl and his school nor Martin Kaehler's theology of needs. What interests us here is the treatment he devotes to the problem of metaphysics. To that we must say that, contrary to his own assumptions (1982: 46f.), he does not arrive at a convincing solution of the problem of meaning and being. What he finds objectionable in classical Thomism as well as in the "neoclassical metaphysics" of process theology is the "categorial" character of their speculation about analogy which he would like to replace with a "literally symbolic one" which can be confirmed in praxis (1982: 133f.).

For this purpose he retains as before Hartshorne's dipolar con- 
ception of God and is not able to make clear the difference between the "categorial" analogy-speculation which he rejects and the nonanalogical "symbolic", "transcendental" metaphysics which he postulates in its place (1982: 143). For even he engages in analogyspeculation when he seeks to reinstate his old fundamental sentence that the quest for the final meaning of our human existence presupposes a "basic faith in the worth of life" (1982: 30).

The difference between his position and that of classical metaphysics, which actually is not capable of giving an account of the Christ-event, consists in the fact that he thinks he can explain Hartshorne's dipolar view of God through this distinction betweenas he says-the "symbolic rather than literal metaphysical assertion" that God "in himself" "as ultimate reality is boundless love" (1982: 144), and the fact that his love "for us" which has the effect of enabling us to deal in love with all our fellow-creatures, is "expressible only in non-cognitive religious language". For the former assertion he refers to the apostolic testimony about experience in Christ. In the latter he expands this view of experience by a reference to the nature of our own experience of love, which "implies not only acting on the other, but also, and just as surely, being acted on by the other" (1982: 145).

In view of this distinction we have to ask: How can Ogden say of the former assertion that it is "not literally metaphysical" although it speaks of what God is "in himself', and how is it possible that such a differentiated experience as he has in mind can be a "non-cognitivist" one? It is not doubted that the representatives of the apostolic witness are not interested in metaphysics, and certainly the praxis of love is something other than a theory of love. But this state of affairs does not become clear in the terminology used by Ogden, but is rather deposed from the intention he has in mind. According to their true intention symbols are the unavoidable as well as necessary "literal" objectifications of an existential self-understanding which experiences itself as related to Transcendence in community (Cf. Buri, 1984).

When Ogden quotes the Parable of the Last Judgment as the conclusion of his Christology and remarks that therein "in no way a christological, or even theological criterion" is brought out (1982: 167 ), and that we are obliged "not only to talk about the point of Christology but also to make it" (1982: 168), we are justified in seeing this as a self-problematization of his theology as well as a hint as to how one can understand him better than he understands himself, namely, that for existence no abolition of risk is possible, but that we can experience ourselves as blessed only in risking ourselves-in theory and in practice. 


\section{III}

Now that we have demonstrated the nature and problematic of the theologies of imagination and process by means of two very different pairs of theologians, we still have to take into account two other theologians who attempt-apparently on the basis of their insight into the insufficiency of both of these kinds of theology-through combining them to overcome their shortcomings and to validate their elements of truth. As already indicated, they are David Tracy and Robert Neville.

Now that Ogden has so sharply criticized the use of analogy in the classical metaphysics of the churchly tradition (1982), David Tracy would not evaluate the theology of Ogden in as positive a manner as he did in an extended treatment of Process Theology in his book, Blessed Rage for Order (1975) and in a longer remark in The Analogical Imagination (1981) where he declares with more reserve:

My own option is basically for the process theology tradition but not, I hope, without a more adequate treatment of some of the subtleties and the complexities of the Thomist (especially transcendental Thomist) position than the latter was accorded in BRO. I continue to believe (as in BRO) that process theologies need to develop and be corrected by the symbolic (and, therefore, radical mystery) side of the tradition and need, as well, a profounder sense of the negative in their developments of analogical language. I remain convinced, however, of the greater basic adequacy of the process tradition for interpreting the central Christian understanding that 'God is Love' and for resonating to a contemporary sense of change, process and internal relationships (see $B R O$, pp. 187-204). Still, the symbolic, the negative and the sense of radical mystery (incomprehensibility, hidden and revealed God, etc.) need more dialectical incorporation into a process systematic theological understanding of God (1981: 439-40).

Despite his denial of analogy, it may be that Ogden who has more recently (1982) advocated a "literal symbolic" conception of metaphysical assertions now complies at least intentionally to some degree with the demand Tracy brings forward vis-à-vis Ogden's earlier position. A closer juxtaposition between them is evident also in the fact that Ogden now advocates the establishing of faith in Jesus Christ on the authority of the apostolic witness (1982: 245)-a point positively stressed by Tracy with respect to Ogden's former position-in a more extensive and emphatic manner.

Despite Tracy's sympathy for Process Philosophy and Ogden's recourse to the "apostolic witness" as a source and norm of faith alongside one's own experience, there remain as before significant differences between the two theologians. Not only does Ogden avoid 
the concept of imagination which has won thematic significance for Tracy in his second book, but the difference between them noted by Tracy that he continues to ascribe "truth value" to "poetic language" over against Ogden's predilection for "non-poetic," "abstract" language (1981: 86) still persists, insofar as Ogden remains, as before, in the service of abstract metaphysical language and shows no interest in the use of literature and art which play a major role in Tracy's thought. It is true, as Tracy indicated, that Whitehead's "subjective principle", in consequence of which man serves as a model of process cosmology, corresponds to the transcendentalism of Rahner's metaphysics-as represented by Tracy-according to which the sought-for metaphysical point of relation is already contained in the question, insofar as in both methods an individual moment of meaning is confidently extended to the meaningfulness of the whole of being (1981: 412ff.). But even in this special kind of "natural theology" we must not overlook the important difference that with Ogden, as is generally the case in Process Philosophy, this metaphysics is represented in a rational way and on the basis of a directly established evolution, while Tracy, following the classical catholic pattern, appeals to analogy as a relation of "similarity in dissimilarity". Strange to say, he does not mention the dogmatized formula of analogia entis as a greater dissimilarity in similarity, but rather prefers to speak of a "soft" metaphysics which he advocates, with Rahner, as opposed to the "hard" classical one (1981: 161).

Wherein then consists the "analogical imagination" from whose formulation as the title of Tracy's second major work we learned the two points by which the latter distinguished himself from Ogden's Process Philosophy? We have already begun to speak of the nature of analogy in the comparison between the Whiteheadian "subjective principle" and the transcendental metaphysics of recent catholic theology, insofar as it determines the relation of immanence and transcendence, or of transcendence in immanence, epistemologically and ontologically. Between these two spheres a being-ful analogy exists, insofar as being is so ordered that from the perspective of human immanence a logical conclusion is possible, not only for being as a whole but also for its transcendent ground. According to the transcendental conception this immanence of transcendence is already present in the epistemological act of transcending and, as such, forms the natural presupposition for supernatural revelation, which on its side functions as the basis of the order of being and so makes possible that epistemological transcending, as Tracy characterized it in the title of his first book (1975).

In his book on analogy-speculation he introduces as his methodology of knowledge the concept of imagination which had been 
occasionally mentioned in his first book (1975:78), and explains it in detail. Referring to the "famous word" of Aristotle, "to spot the similar in the dissimilar is the mark of poetic genius" (1981:410), Tracy combines analogy with imagination as "a reflection upon the self s primordial experience of its similarity-in-difference to the event" (1981: 410). Between both of them exists a dialectical relationship insofar that "the same power-at once participatory in the originating sense of wonder, trust, disclosure and concealment by the whole, and positively distancing itself from that event by its own self-constituting demands of critical reflection-releases the analogical imagination of the systematic theologians to note the profound similarities-indifference in all reality" (1981: 410).

As is evident from this quotation and its context, the event that is here at stake is a "religious event", or more precisely, the "Christevent" and its efficacy as "all pervasive grace". But Tracy"s intention is to see in this analogical imagination not merely an affair of theology; rather he wants to exemplify its theological application to the spheres of literature and art in their classical formulations, which for their understanding require the same methods as the Bible and the Christian tradition and teaching on the reality of God in general and salvation in Christ in particular. While earlier (1975) he viewed the revelation of transcendence in a dialectic of the limit of thinking as a self-manfestation of that which limits ("limit to" = "limit of"), later (1981) he unfolded the same dialectic in relation to the christological salvation-event and its "not yet and already"-in one case as the shattering of conceptual-objective knowing which has to be taken into account in the use of a symbol, and in the other case-in view of the problematic of the fundamental presupposition of the Christian faith-as the claim that the promised salvation in Christ has already occurred, but-in view of the non-arrival of the Parousia-has always to occur anew (1981: 252ff.).

In view of this irritating state of affairs Tracy speaks repeatedly of the "dangerous, provocative, subversive" memory of Jesus of Nazareth (1981: 424, passim). On the one hand he sees therein a warning against every false desire for harmony as it belongs to religiosity (1981: 154ff.). On the other hand he points to the whole of the Christian tradition and its classic formulations preserved in the Church as an indispensable help (1981: 164, 235ff.). Trust in these instances is for him included in trust in God's love revealed-albeit in a dialectical manner-in Christ, which-in accord with the nature of this faith-is to be extended through the analogical imagination to the whole of "God, man and world" in a way which justifies in an unending dialectic a pluralism of interpretations and religious bodies (1981: 447). 
That is the manner in which Tracy would correct the Process Theology of his friend Ogden through analogical imagination. In accord with this intention he restricts the attempt by process theology to ground cosmologically the meaning of human existence in the meaning of being as a whole to an interpretation of meaning in the realm of social history effected on the basis of the Christian faith. If Ogden would see the relation between his experience of God's love witnessed in the apostolic faith and his own personal love-faith experience in a less rationalistic and metaphysical and more poetic, imaginative way, he could probably follow Tracy on his way to Rome, although this way would still need some analogical imagination even for Tracy. But I fear, or hope, that for both theologians the "dangerous memory of Jesus" would be a blessed obstacle on the way, since-as Tracy once concedes and Ogden takes quite seriously-to it belongs the fact of the non-arrival of the Parousia (1981: 265f.) as the great paradigm of the foundering of all universal constructions of meaning-a shattering that could become the symbol of true realization of meaning, if it is not eliminated, historically by Tracy, psychologically by Ogden, to their detriment.

Robert Neville has chosen another path on which he did not stop in the Christian West, but on which his Daimon guided him to the Tao of the Far East.

That and how we conclude the series of our selected representatives of American theology and philosophy of religion with Robert Neville results from the fact that he is, on the one hand, a keen-sighted critic of the theologies of imagination and process, and on the other, that as an equally great systematic thinker, he tries in one system to bring together the concerns and results of the two kinds of theology corrected by him, trusting that he is able to do justice to Christian faith in creation and redemption as well as to the Tao of Far Eastern thinking in a completion that unites the two.

In contrast to the ontological problematic of Hart's concept of event and Kaufman's use of imagination as pragmatic satisfaction of need, Neville univocally defines the nature of imagination as valuation bound up with norms in the context of the experience of thinking. Against their claim to overcome the subject-object split of consciousness, he reproaches the representatives of Process Philosophy and Theology for still treating process as an object and only in such a way that the subject of thinking as well as the subjectivity of God become problematic, insofar as one does not know who is doing the thinking, the process-event or the thinking subject, and insofar as the identity or non-identity of God with this process, or with its thinker, does not become clear (Cf. especially:1980). In his major, unfinished work (1981a), he contends-against the aprioristic-rationalistic character of 
Kant's transcendental imagination-that it does not in his judgment take valuing feeling into account and is not able to explain the source of the forms of representation and the concepts of reason (1981a: 149ff.). He will hold fast to the "Naturalism" of Process Thought, insofar as he understands it to be far more differentiated than do its other representatives (1981a: 68ff.).

Neville's reconstruction of thinking represents an extremely differentiated network of several interrelated kinds of thinking whicheach in its own way-appear in the special realms of the spirit and of culture and in which they validate their criteria. Imagination forms for Neville the starting-point and final basis of thinking. It consists in a valuing selection of individual components out of the manifoldness of experience, and the norm consists in their adaptibility into the totality of a harmony of "beauty". Religion is the pre-eminent field of appearance of this imagination. But thinking does not exhaust itself in imagination, for it involves a further structural element-interpretation-in which the contents of thought are tested for their "truth"-a criterion which is important in the field of "politics", but which plays no role in imagination itself. Furthermore, thinking demands theory which intends "formal unity" and results in "knowledge". This series concludes with the responsibility of the valuing one for his valuation in the "philosophical life" as "obligation to goodness" (1981a: 27ff.). Despite their differences these four aspects are not to be separated, but in fact entail each other, in that on the one side the valuing imagination continues in the succeeding ones as they presuppose it, and on the other side because responsibility is actualized in those which precede it.

Of this complex system of an "Axiology of Thinking" Neville has so far produced only the first part, viz. the imagination, and only indicated the pertinent parts which are to follow, so that it is not possible for us to make a conclusive judgment about his pretentious undertaking. Nevertheless, systematic difficulties are evident in what has appeared already, in that in the preview of the whole work "beauty" as a criterion is ascribed to the synthetic function of the imagination (1981a: 18), whereas in the exposition of the imagination in the present volume, in which interpretation forms an aspect of imagination, it is assigned to the sphere of "perception" in the "interpretation" (1981a: 177f.).

Another more important difficulty with which Neville is obviously struggling, is evident in the different location of imagination in the series of the different structures of thinking. While in his main work he places imagination at the beginning and allows thinking to begin with imagination (1981a: 135), in the recent sequel to it (1982: 236), it stands only in the third place, after interpretation and theory. Of 
course he does not fail to emphasize immediately that this "third dimension"-the imagination-is "in fact the one on which the others rest". But why doesn't he admit at the beginning, as he does in his basic theses, that thinking is grounded in "valuation", which first appears in imagination (1981a: $x, 146 f$.), since this corresponds to the detailed analysis in this work and also agrees with what he set forth briefly in his later work (1982)? These final concluding remarks in the latter work are so instructive that a long citation is here in order:

I use the word imagination here roughly as Kant did-to mean the basic activities of synthesis by which various causal impingements of the environment are transformed into the stuff of experience. The goal of the imagination is engagement. Images, the basic forms of imagination, are the terms in which experience is taken up; they constitute the basic orders of the world. In fact, they constitute the world in a crucial sense. Experience orders what otherwise would be merely mechanical pushes into a world with spatial and temporal dimensions, values and interests, vectors of forces and possibilities with various degrees of attractiveness. The function of imagination is to supply this order so that the other dimensions of thinking have structure and horizons in which to exist. This is not to say that the world is a solipsistic, subjective construct or that there is no external world; rather it is to say that the way human beings experience external elements is to "worldize" them. Any consideration of the truth of a particular assertion about what is real is based on, and therefore relative to, its own imagery, its own fundamental structure (1982: 236f.).

Anyone who is at least to some extent familiar with "the transcendental deduction of the pure concepts of understanding", which as is well known belongs to the most difficult and problematic sections of Kant's Critique of Pure Reason, will doubtless recognize the differences between Neville's and Kant's understanding of imagination which the former-in a way different from this summary-demonstrates in various places in (1981a: Cf. index, p. 342). Neville replaces Kant's apriori forms of intuition and understanding with the pictorial world of imagination. Although he also adds to these both "interpretation" and "theory", he exempts himself from the difficulties associated with the apriority of these forms, but at the same time through this connection of interpretation and theory with the imagination he ascribes to the latter the capacity for knowing "external reality" which Kant's restriction to its phenomenality does not permit.

Whereas proper theologians of imagination, with their images, do not escape the suspicion of an illusory wishful thinking, Neville can refer for his imaginal world to Process Philosophy in which these form a constituent part of reality conceived as process, but only so at the expense of the "unity of self-consciousness" which, according to Kant, 
accompanies all acts of thinking and which finally grounds their character as reality. The loss of the self in exchange for a "self-less", universal occurrence which is ultimately identical with some kind of impersonal deity is the price Neville has to pay for his overcoming of Kant through his processual theology of imagination, in which God becomes for him the "creativity" of the Holy Spirit (1981b). This problematic becomes most apparent in Neville's positive advance into the Far Eastern idea of the Tao, in which the dualism represented by Hart and Kaufman, and inherent in Kant as well, is replaced by a monism of being, and through a radically understood Pratityasamutpada even the last vestige of objectivity in Whitehead's "concrescence" is overcome. He believes he can succeed in his attempt to secure the Daimon of theory might emerge. This could happen, however, not in a universal speculation about imagination or process, but only in a Christological theology of a self-understanding which experiences itself as related to its special Transcendence and which forms the basis of a community with a corresponding structure.

IV

To present such a theology here, even in its bare essentials, would exceed the framework of what could be expected of me as my task and far exceed the time we have at our disposal. As an indication of the epistemological and metaphysical structures of such a theology, I shall be content to close with some concise principles for appropriately treating the problem of meaning and being which could help a bit to clarify and correct the six types of contemporary American theology already discussed, so that they not only remain typically American, but may become even a bit more Christian.

For this aim we sum up the critical viewpoints used in the preceding in the following manner.

The two terms of the problem of meaning and being, namely, meaning and being, can and must be conceived at the same time as different as well as inseparable:

Meaning, first, as an (as much as possible) univocal designation of something meant in logical conceptuality, which in view of what is meant-constitutes an abstraction and always remains relative. This relativity becomes even stronger when what is at stake is not an (as much as possible) objective explaining, but an interpreting of what is meant in its subsequent enactment in a subjective valuing which, together with explaining, belongs to understanding.

This leads us, in the second place, to meaning as value which is characterized by the fact that its being is preferred to its non-being. This concept of value is only possible where the concept of meaning 
is understood as a striving for logical univocity and gives to the formality of the latter its being-ful content. Over against what is unknown even what is only relatively known represents a value, even though it is not possible on the basis of the first mentioned concept of meaning to establish an absolute order of value.

The connection between these two concepts of meaning-meaning as designation and meaning as value-leads necessarily to a corresponding differentiation in the concept of being:

First, we are dealing in the first instance in this meaning-thinking with a being rather than with the being which must for conceptual thinking remain a void.

Second, we can conceive being neither as the sum of all beings in the sense of the first concept of meaning-because in it we are always dealing only with a part of the totality of being-nor can we "mean" it as the foundation of beings without making it into a being.

While the being that is available to us only in this particularity remains a riddle both in itself and in relation to those of us who interrogate the meaning of our existence, in our self-understandingwhich represents a void for our conceptualizing as well as for being, but nevertheless remains the root of our consciousness of being-we experience the mystery of being in a special way, namely, as the origin of what is for us the problematic of meaning and being. For man, because of the problem of meaning, being becomes a crisis and therein exhibits itself in its transcendence which can only be spoken of in symbols as indispensable objectifications of what is not objectifiable.

Philosophical and religious worldviews are expressions of this crisis as well as questionable attempts to overcome it. In theology, corresponding to these different philosophical connections or antitheses of meaning as designations of what is meant and meaning as value is the distinction or relationship between reason and faith. The problematic of the concept of being in the ontological difference is reflected in the distinction between God as Creator and the creatureliness of his creation, on the one hand, and on the other, between God as Redeemer and his salvation history in the salvific work of his Sonboth united in the open mystery of the Trinity.

The problem of language is evident in philosophy as well as theology in the possibilities of mystical silence and the existential interpretation of objectifying mythology and speculation as the basis of a dialogue with other religions, and of a positive, critical attitude toward their redeemer figures. While the silence grows out of the awareness of the mystery of being and its riddle of meaning, the existential interpretation has the function of endowing that awareness with speech as a special revelation of the mystery of being by making 
possible particular realizations of meaning as a grace of being. It is the destiny of religions to inform one another in theory and practice of such real possibilities of individually restricted experiences of solutions of the problem of meaning and being and thereby to understand themselves and one another more deeply.

In Christianity the problem of meaning and being takes a special form, because in its historical origin it arose out of the non-fulfillment of the eschatological, being-ful expectation of meaning, or out of its transformation in the different churches based on this hope and their means of salvation. Christianity will have to do with the truth in respect to itself as well as in contrast to other conceptions of salvation only to the extent that it absolutizes none of the alleged solutions to the problematic of its origin which have arisen in the course of history, but rather sees in them only housings which have repeatedly to be dismantled in order to see itself constantly confronted anew with the problem of meaning and being, as we have experienced it in a partial way in our debate with six American theologians. Even in their self-conscious failures I know myself to be with them on the way to a future Christian theology, and I hope that you will in your own manner accompany us.

\section{WORKS CONSULTED}

Buri, Fritz

$1970 / 1973$

1982

1984
$1956 / 1962 / 1978$

Dogmatik als Selbstverständnis des christlichen Glaubens. 3 Volumes. Bern: Paul Haupt Verlag. Gott in Amerika. 2 Volumes. Bern: Paul Haupt Verlag. Der Buddha-Christus als der Herr des wahren Selbst. Bern: Paul Haupt Verlag.

"Bedeutung und Problematik der Christologie Schubert Ogdens." Theologische Zeitschrift 40, 223-28.

Cobb, John B., Jr. 1975 1982

Christ in a Pluralistic Age. Philadelphia: Westminster. Beyond Dialogue: Toward a Mutual Transformation of Christianity and Buddhism. Philadelphia: Fortress.

Cobb, John B., Jr. and Griffin, David Ray 1976 Process Theology: An Introductory Exposition. Philadelphia: Westminster.

Hart, Ray L. 1968
Unfinished Man and the Imagination: Toward an Ontology and $a$ Rhetoric of Revelation. New York: Herder and Herder. 


\section{THE LOGIC OF DETERRENCE Anthony Kenny}

In this pithy "everyman's guide" to the theory and ethics of nuclear war and deterrence, a noted philosopher casts a critical eye on the current policies of both East and West. Putting forward his own strong proposals, Kenny calls for a series of phased and partial unilateral steps by the West, coupled with pressure on the East to reciprocate.

Paper $\$ 6.95128$ pages

Library cloth edition $\$ 20.00$

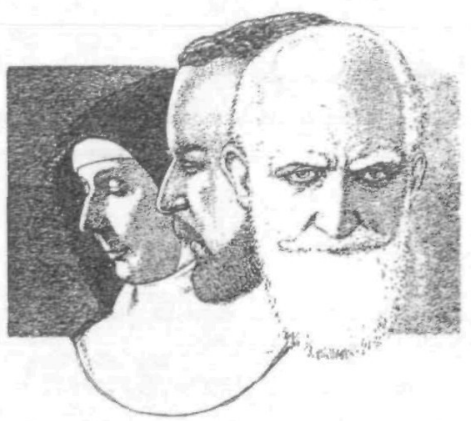

THE NUN,

THE INFIDEL, AND

THE SUPERMAN

The Remarkable Friendships of Dame Laurentia McLachlan with Sydney Cockerell, Bernard Shaw, and Others

\section{Felicitas Corrigan}

Although Dame Laurentia McLachlan (1866-1953) was for sixty years a strictly enclosed nun, the world came to her in admiration of her intellectual powers as musician, scholar, and administrator. The story of Dame Laurentia's friendship is told here, in the words of the Times Literary Sup plement, "with a rare and refreshing innocence."

Cloth $\$ 14.95$

152 pages 5 b\&w photographs

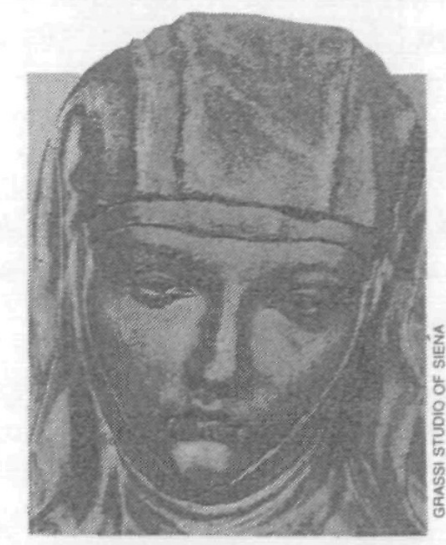

\section{HOLY ANOREXIA}

Rudolph M. Bell

Epilogue by William N. Davis

Tracing the persistence of forms 'of anorexia through history, Bell suggests that for both the anorexic and the fasting saint self-starvation is part of a larger struggle for liberation from a partriarchal family and society. "Bell has done a remarkable job: he relates the religious life to psychology without reducing it to psychological factors."-Richard

Kieckhefer, Northwestern University Cloth $\$ 22.50 \quad 260$ pages

$18 \mathrm{~b} \& w$ photographs

\section{Now in paper}

\section{THE CHRISTIAN TRADITION} A History of the Development of Doctrine Volume 4: Reformation of Church and Dogma (1300-1700) Jaroslav Pelikan

"Pelikan's The Christian Tradition [is] a series for which they must have coined words like 'magisterial."-

Martin E. Marty, Commonweal $\$ 14.95478$ pages 
Kaufman, Gordon D.

1968 Systematic Theology: A Historicist Perspective. New York: Charles Scribner's Sons.

1972 God the Problem. Cambridge: Harvard University Press.

1979 An Essay on Theological Method. Revised Edition. Missoula, MT: Scholars Press. Orig. publ., 1975.

1981 The Theological Imagination: Constructing the Concept of God. Philadelphia: Westminster.

Neville, Robert C.

1980

Creativity and God: A Challenge to Process Theology. New York: Seabury.

1981a Reconstruction of Thinking. Vol. 1, Axiology of Thinking. Albany: State University of New York Press.

$1981 \mathrm{~b} \quad$ "The Holy Spirit of God." In Is God GOD?, 233-64. Ed. by Axel D. Steuer and James Wm. McClendon, Jr. Nashville: Abingdon.

1982 The Tao and the Daimon: Segments of a Religious Inquiry. Albany: State University of New York Press.

Ogden, Schubert M.

1966

The Reality of God and Other Essays. New York: Harper \& Row.

1982 The Point of Christology. San Francisco: Harper \& Row.

Tracy, David 1975

1981
Blessed Rage for Order: The New Pluralism in Theology. New York: Seabury.

The Andlogical Imagination: Christian Theology and the Culture of Pluralism. New York: Crossroad. 


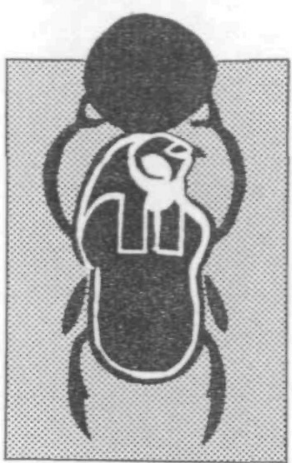

THE GREEK MAGICAL PAPYRI IN TRANSLATION Including the Demotic Spells Volume 1: Texts Edited by Hans Dieter Betz

This volume contains the first English translation of "the Greek magical papyri"-a collection of magical spells and formulas, hymns, and rituals from Greco-Roman Egypt-and related Coptic and Demotic texts. Cloth $\$ 39.95448$ pages Illustrated throughout

\section{A HISTORY OF RELIGIOUS IDEAS}

Volume 3:

From Muhammad

to the Age of Reforms

Mircea Eliade

Translated by Alf Hiltebeitel and Diane Apostolos-Cappadona Completing his immensely learned History of Religious Ideas, Eliade traces the movement of Jewish thought out of ancient Eurasia, the Christian transformation of the Mediterranean area and Europe, and the rise of Islam and its diffusion from approximately the sixth through the seventeenth centuries.

Cloth \$27.50 352 pages
WISDOM AND THE HEBREW EPIC

Ben Sira's Hymn in

Praise of the Fathers

Burton L. Mack

Placing Ben Sira's hymn in its historical, religious, and social contexts,

Mack shows how this unlikely poem created a mythic charter for Second Temple Judaism. "Wisdom and the Hebrew Epic shows an enviable. breadth and depth of vision."--Jon D. Levenson, University of Chicago

Cloth $\$ 25.00280$ pages

Chicago Studies in the

History of Judaism

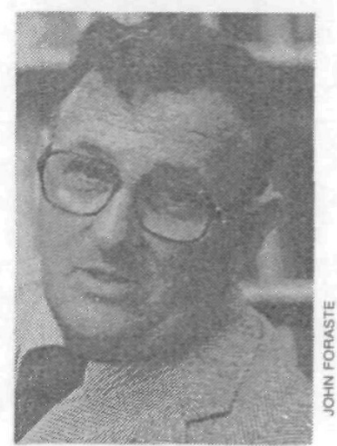

\section{JUDAISM}

\section{AND SCRIPTURE}

The Evidence of

the Leviticus Rabbah

Jacob Neusner

This groundbreaking work continues Neusner's multi-volume examination of the main texts of Judaism in its formative years. In Judaism and Scripture Neusner moves from the study of ancient Judaism in society at large to an analysis of Rabbinic Judaism in relation to Scripture itself. Cloth $\$ 50.00$ (est.) 656 pages Chicago Studies in the History of Judaism 


\section{A Short History of Christian Thought}

P. LINWOOD URBAN, Swarthmore College

This introduction to the history of Christian thought is organized around the great issues in Christianity. Questions of doctrine, such as the Trinity and the Incarnation, are dealt with in full, as well as the important issues in natural theology, such as the existence of God, freedom of will, and the problem of evil. Urban traces the roots of Christian doctrine to their sources, explaining why certain doctrines were adopted, and which ones are logically essential to Christianity. In examining the modern implications of the basic components of Christian thought, he demonstrates that the foundations of Christian belief are largely rational and that Christian thought, through history, has encompassed the full range of human experience.

\section{February 1986250 pp. paper $\$ 10.95$ cloth $\$ 27.95$}

\section{Oxford Bible Atlas Third Edition}

Edited by HERBERT G. MAY; revised by JOHN DAY, University of Oxford

"Having used virtually every modern Bible atlas, including earlier editions of the Oxford Bible Atlas, it is my opinion that this excels them all in almost every respect. The gazatteer is without equal and the text accurate and informative." - Eugene H. Merrill, Dallas Theological Seminary. Incorporating the most recent advances in biblical studies, archaeology, and topography, this superb guide to the geography of the Holy Land has now been brought completely up to date. Important revisions include: the relocation of many sites in the maps; thorough textual changes, especially with regard to chronology, the Exodus, archaeology, and the patriarchs and New Testament Jerusalem; diacritical points added to the spelling of Arabic place names; and new illustrations replacing those that were found to be outdated.

1985144 pp.; 26 color maps, 90 halftones paper $\$ 9.95$ cloth $\$ 18.95$

\section{Medieval Women's Visionary Literature}

Edited with commentary by ELIZABETH ALVILDA PETROFF, University of Massachusetts, Amherst

This unique sourcebook captures a thousand years of devotional and visionary writing by medieval women from many different cultures, traditions, and backgrounds: founders of religious communities, hermits and recluses, wives and mothers, wandering teachers, heretics, and reformers. Ranging in time from late antiquity to the 15 th century, the writings include examples of lyric poetry, drama -including the first play ever written by a woman - epics, saints lives, and letters, as well as an Inquisition deposition and some newly invented genres such as spiritual autobiography, the guide to prayer, and progression of visions.

January 1986416 pp. paper $\$ 12.95$ cloth $\$ 29.95$

Prices and publication dates are subject to change.

To request an examination copy, send full course information, including course title, level, expected enrollment, and decision deadline to: College Humanities and Social Sciences Marketing 